\title{
神経調節機能を参考とした自律エージェントの神経制御器の開発
}

\section{Development of Neural Controller \\ for Autonomous Agent based on the Neuromoduration System}

\author{
菅 佑樹 (早大) 小林大三 (早大) 尾形哲也 (京大) 菅野 重樹 (早大) \\ Yuki Suga (Waseda Univ.) Daizo Kobayashi (Waseda Univ.) \\ Tetsuya Ogata (Kyoto Univ.) Shigeki Sugano (Waseda Univ.)
}

\begin{abstract}
Our goal is to create an autonomous robot which can communicate with people for a long time. In this paper, a emotional motion generation algorithm constructed of an endocrine system model and a neural network algorithm is described. We carried out an experiment to survey the adaptability and flexibility of the robot's behaviors. As the result, the robot with our proposing algorithm could adapt to the simulated environment including a predetor which discharges the robot's battery.
\end{abstract}

Key Words: Human-Robot Interaction, Communication Neuromodulation

\section{1.はじめに}

我々の研究目的は，人間とコミュニケーションする 自律ロボットの開発にある。

複雑な環境内を自律的に行動するロボットには，様々 な問題が付きまとうものであるが，本研究では特に，部 分観測環境下におけるセンサ情報の時系列的な取り扱 いに着目している。実環境下で行動する自律ロボット は，身体という限られたリソースを用いているため，セ ンシング範囲が限られてしまう。このため, 複雑な環 境下では，以前とは異なる状況にあってもセンサから 得られる情報は同一のものとなる場合が起こる。この ような部分観測環境下における行動においては，過去 のセンサ入力まで遡り，情報を時系列的に扱いながら 行動生成卞ることが有効であると考えられる。

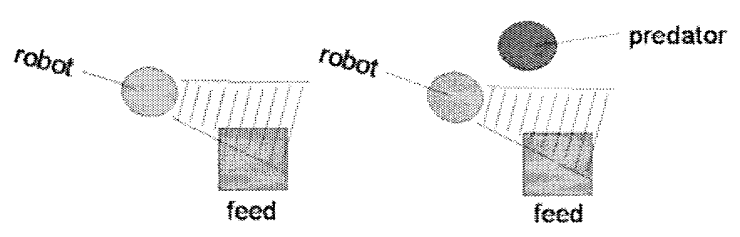

Fig.1 Partially Observable World

このように，センサ情報を時系列的に扱うことがで きるアルゴリズムのうち, 代表的なものとして, Recurrent Neural Network (RNN) がある. RNN とは, Neural Network (NN) の出力層を再び入力層に接続したもので ある.これにより, 直前の出力を入力とすることで力学 系モデルを内包し, 時系列的な問題をモデル化すること ができる. RNN は工学や脳科学が融合した分野で様々 な研究が行われており，非常に有用なツールである。

一方で我々は，生物の内分泌系を模倣した，緩やか なダイナミクスを持つモデルを工学的に応用したアプ ローチを取っている。このアプローチでは, 出力行動 を決定するアルゴリズムと並列して，センサから得ら れた情報を用いて内分泌系モデルを変化させる。この 内分泌系モデルの緩やかなダイナミクスにより, 過去 のセンサ情報が一定時間影響を及ぼすことで，センサ
情報の時系列的な扱いが可能になると考えられる。こ の手法はRNNに比べると非常に簡素なシステムであ り，非線形かつ複雑な行動決定などに用いることは困 難であるが，時間的な影響度などをパラメータによっ て操作することが容易で, 実験後の解析が行い易い. 近年, 生物の内分泌系を模した, 緩やかなダイナミク スを持つモデルを工学的に応用したアプローチが研究 されている。例えば Canamero et. al. は, Subsumption Architecture (SA) の行動選択にホルモンを応用したシ ステムが提案している2). しかし，SA では各行動要素 を事前に定義しておく必要があるため, 行動の多様性 に欠ける。本研究では, 創発的なコミュニケーション 知能の開発を目的としているため, センサーモー夕協 調レベルでのロボットの行動制御アルゴリズムを用い ている。これまでに，変化のない静的な環境下で，デッ ドロック回避などのタスクに内分泌系モデルが有効で ある事を示した?)。しかし，内分必系モデルの行動生 成系への影響については，アクチュエータの出力に強 弱をつけるのみであったため, 本稿では内分泌系モデ ルの影響をアクチュエータの出力方向にまで影響を与 える実験を行ったので報告を行う。

\section{2. 提案するシステム}

近年, 反射的な行動生成を行なう生物で, ホルモン が神経系の結合加重や閾值を動的に変化させる神経調 節という機能が確認されている ${ }^{3)}$ 。 そこで,この神経 調節機能を内分泌モデルに応用する事で, 分必される ホルモンが作用する間, 動的にセンサ入出力特性を大 きく変化させ，前述した問題に対応できる行動生成が 可能だと考えられる.

Fig. 2 に今回提案するシステムを示す。提案するシス テムは 2 層の NNと内分必系モデル (ES) によって構成 される。

ES は各センサ入力を, それぞれのセンサにおける故 障率を算出する関数 (自己保存評価関数) に基ついて 評価をし，各センサにおける自己保存評価值 $P_{i}(t)$ を算 出する $\left(P_{i}(t)\right.$ は, 時間 $t$ における $i$ 番目のセンサの自己 保存評価值を表す）。またここで， $P_{i}(t)$ の值が大きい ほど，故障率が高い状態にあるといえる，そして，各 


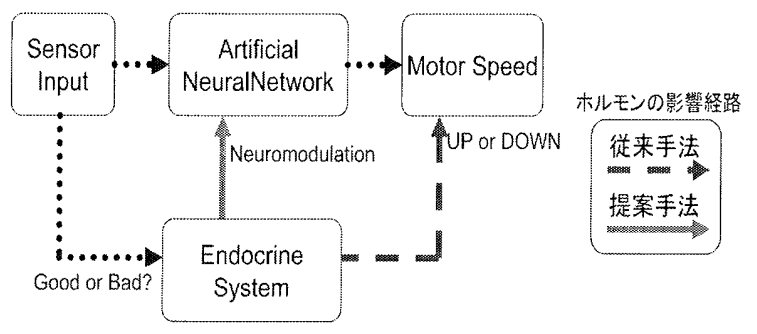

Fig.2 Proposed System

センサの $P_{i}(t)$ の最大值を，このロボット全体の自己保 存評価值 $P(t)$ とし, 直前制御ステップにおける自己保 存評価值 $P(t 1)$ との差分 $\delta P(t)$ と絶対值 $P(t) j$ に基 づき, 4 種類のホルモンを分泌する.

各種ホルモンが作用する間, NN から成る行動生成 器では, シナプス結合荷重が変化する。

\section{3. 評価実験}

\section{1 実験環境}

本手法の有効性を確認するため, 提案手法と, 本プ ロジェクトにおける従来手法を各々実装したロボット の生存時間の比較実験を行った。ここでいう従来手法 とは, 行動生成器となる 2 層 $\mathrm{NN}$ と, パラメー夕変化を 及ぼす ES はそのままに，ESが及ぼす変化をアクチュ エータの速度にのみ影響を与えるシステムである。

実験環境を Fig.3に示す，四角い部屋にロボットの充 電ステーション (赤) と外敵 (青) を配置した。この 中でロボットは，限られたバッテリの電流を消費しな がら, 外敵から避け，また充電ステーションでバッテ リの充電をすることで生存していくものとする。この 実験ではロボットの生存時間を評価軸として, 従来手 法と本手法の有效性について比較を行った。

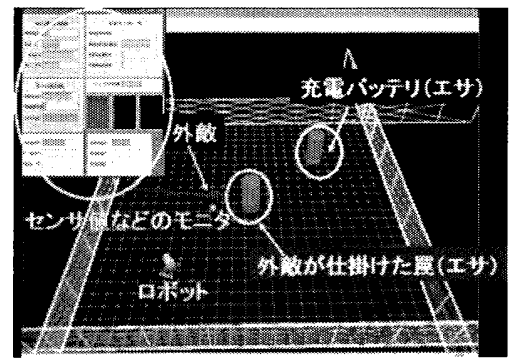

Fig.3 Environment

本実験の環境において，ロボットが充電ステーショ ンに接触すると，バッテリが直ちに満充電され，しば らくの間環境から充電ステーションは消失する。また 外敵は, 環境中央に配置された充電ステーションの周 用をランダムに探索行動を行っており，視界にロボッ 卜が補足されると，そのロボットに対して真っ直ぐア プローチを行う。そして外敵がロボットに接触すると, ロボットのバッテリのすべての容量が奪われる.

\section{2 自律ロボット WAMOEBA-3}

本研究で用いた自律ロボットWAMOEBA-3 は, セン サはバッテリ電圧センサ，超音波センサ，視覚として カメラを使用し、すべてのセンサの值は行動生成器（2
層 NN）に入力される。アクチュエータは台車モータの みで，前進，および左右旋回行動が NNの出力によっ て行なわれる。

NNのパラメータは，次のように設定した。本稿にお ける実験では，シナプス結合荷重と $P_{t h}$ をはじめとする ESに関するパラメータは，予備実験において生存時間 が長くなるように try-and-error で決定された。また従 来手法においても try-and-error を用いたが, こちらに ついては生存時間を評価值とした遺伝的アルゴリズム （GA）でパラメータの微調整を行った。

\section{4. 実験結果}

以上の設定で，各々の代表個体を用い，ロボットの 初期位置をランダムに変えて 350 回試行を繰り返した。

実験の結果得られた各手法での評価值，すなわちロ ボットの生存時間を Fig.4 に示す。提案手法ではロボッ 卜の生存時間が従来手法に比べて有意に長くなる事を 確認した $(P<001)$. また， ロボットの行動解析を行っ た結果, 提案手法においてのみ, 外敵を知覚した後し ばらくの間は, 充電行動よりも外敵からの回避行動を 優先して行ったことが分かった。

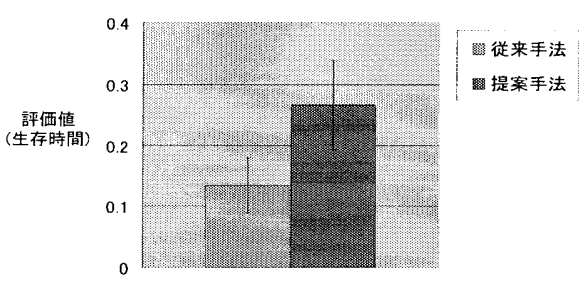

Fig.4 Impression of experiments

\section{5. まとめ}

本研究では，時間的影響を考慮した行動生成システ ムとして，神経調節機能を有する内分泌モデルを提案 した。その結果，提案手法によって，部分観測下にお ける時系列的な問題に対応できる行動生成が可能にな り，本手法の有効性が示された。

今後は進化的手法を用いたパラメー夕設定について 研究を行っていく.

\section{謝辞}

本研究の一部は，日本学術振與会 21 世紀 COE プログラ 么「超高齢化社会における人とロボット技術の共生」と，岐 皁県WABOT-HOUSE プロジェクトの支援を受けて実施しま した。ここに謝意を表します。

\section{参考文献}

1) Ogata, T., Sugano, S.: Emotional Communication Between Humans and the Autonomous Robot which has the Emotion Model, Proc. of IEEE Int'l Conf. on Robotics and Automation (ICRA'99), pp.3177-3182, 1999.

2) Canamero: Hormonal modulation of perception in motivation-based action selection architectures, Computational modeling of emotion, 2005.

3) Nagao, T., Gatellier, L., Kanzaki, R.: Serotonin modifies the sensitivity of the male silkmoth to pheromone, Journal of Experimental Biology 207, 2487-2496 (2004) 